\title{
Gene Therapy for Hearing Protection
}

\author{
Min Young Lee \\ Department of Otorhinolaryngology-Head \& Neck Surgery, Dankook University Hospital, College of Medicine, Dankook University, \\ Cheonan, Korea
}

\section{청력 보호를 위한 유전자 치료}

이 민 영

단국대학교 의과대학 단국대학교병원 이비인후과학교실

\author{
Received June 1, 2017 \\ Revised June 9, 2017 \\ Accepted June 9, 2017 \\ Address for correspondence \\ Min Young Lee, MD \\ Department of Otorhinolaryngology- \\ Head \& Neck Surgery, \\ Dankook University Hospital, \\ College of Medicine, \\ Dankook University, \\ 201 Manghyang-ro, Dongnam-gu, \\ Cheonan 31116, Korea \\ Tel +82-41-550-1785 \\ Fax +82-41-561-3485 \\ E-mail eyeglass210@gmail.com
}

Sensorineural hearing loss (SNHL) does not recover and only few exceptions exist. It is mostly due to the reason that hair cells in the cochlea cannot regenerate once damaged. Therefore, clinical approaches for SNHL mostly rely on the implantable or external device to deliver sound to brain. Despite the advance of technology, current strategy does not replicate the sound perception of naïve inner ear. To overcome this issue, novel trials to protect or rescue hair cells from the ototoxic insults are investigated. One of these is gene therapy. Protective gene therapy has been applied to several ototoxic insults, but some trials have shown negative effect. Gene therapy using neurotrophin, one of the growth factor, has been expected to show protective effect against acoustic overexposure. But unregulated and untargeted expression of $\mathrm{Ntf} 3$ revealed adverse effect showing deterioration of nerve ending and synapse. Meanwhile, gene therapies have been adopted and tried for cisplatin ototoxicity. Most of the studies has been shown promising outcome. Also several studies have shown protective effect of gene therapy for aminoglycoside ototoxicity. Recent publication showed that heat-shock protein 70 was effective in preventing aminoglycoside ototoxicity. Furthermore, use of gene therapy expands to the field of cochlear implant, in which it can be used as an enhancer of treatment outcome. Application of neurotrophins resulted in increase of spiral ganglion densities as well as migration of peripheral nervous fibers to the location which would be closer to the electrode when implanted.

Korean J Otorhinolaryngol-Head Neck Surg 2017;60(6):263-70

Key Words Gene therapy $\cdot$ Hearing $\cdot$ Protection.

\section{서 론}

감각 신경성 난청(sensorineural hearing loss)은 많은 경우 에서 쉽게 회복되지 않는다. 돌발성 난청이 스테로이드 치료 이후 청력이 회복되기도 하고 혹은 메니에르병(Meniere's disease)의 청력이 상황에 따라 변하는 경우가 유일한 예외일 것이다. 이렇게 감각 신경성 난청의 회복 혹은 치료가 어려운 이유는 와우의 유모세포와 그에 접해 있는 신경 조직들이

This is an Open Access article distributed under the terms of the Creative Commons Attribution Non-Commercial License (http://creativecommons.org/licenses/by-nc/4.0) which permits unrestricted non-commercial use, distribution, and reproduction in any medium, provided the original work is properly cited.
손상이 된 후에 재생되지 않기 때문이며 또한 유전자 돌연변 이에 의한 감각 신경성 난청도 치료가 불가능하기 때문이다. 따라서 감각 신경성 난청의 적절한 생물학적 치료 방법이 없기 때문에 인공와우(cochlear implant)나 보청기(hearing aid) 등 을 이용하여 소리를 증폭해 주는 방법이 임상에서 흔히 사용 된다. 이러한 보조 기구 중 특히 인공와우가 고도 난청 환자 들에게는 매우 유용하고 효과적이지만 아직까지는 정상 와우 를 가진 사람이 듣는 소리의 질을 완벽히 따라갈 수는 없다. 이에 보다 나은 소리를 들을 수 있는 방법과 신개념 치료 방법 개발을 위한 노력들이 필요하다. 한편 최근에는 유전성 난청 에 대한 배경지식의 증가 및 연구결과들이 보고되고 있고, 유 
전자 치료의 도입 그리고 인간의 질병과 상황이 아주 유사한 동물 모델 확립으로 내이의 기능의 보호 및 재생을 위한 연구 들이 활발히 진행되고 있다.

본 리뷰에서는 유전적 물질을 대상 세포에 전달함으로써 그 치료 목적을 달성하는 방법으로 유전자 치료 방법에 대해서 기술하고자 한다. 이러한 유전자 치료는 대부분 viral vector 라고 불리는 변형된 바이러스를 이용하게 되는데, viral vector 들이 세포 안으로 들어가서 전달 물질(대부분의 경우 유전자) 을 전달하게 된다. 혹은 siRNA, small molecule들을 이용하 게 되는데, 이러한 인자들은 각종 유전자 발현을 증가 혹은 억제시킬 수 있는 능력을 보유하고 있다. 와우로 물질을 전달 하는 루트로는 여러 가지가 있다. 그중 대표적인 것이 중이강 안으로 투여하는 경고막(trans-tympanic)이 있고, 좀 더 침습 적인 방법으로는 정원창(round window)으로 직접 투여하는 trans-round window 투여와 와우 혹은 전정기관에 직접 구멍 을 뜷고 투여하는 cochleostomy 혹은 canalostomy가 있겠다 (Fig. 1). ${ }^{1)}$ 대부분의 경우에서 전달 루트의 결정은 치료 대상 세 포의 위치와 viral vector의 종류에 의해 결정된다. Viral vector 의 종류에 따라 그 전달 영역의 차이가 나게 된다. 내이의 와우 로 어떠한 물질을 전달하는 것은 쉬운 일이 아니다. 하지만 와 우가 액체로 충만된 폐쇄 공간이기 때문에 전달 물질의 와우 내 확산이 유리하고, 와우 외로의 전파가 어려운 장점이 있다.

저자는 유전자 치료를 이용한 청각 보호에 관한 내용들 위 주로 서술하고자 한다. 크게 나누면 여러 가지 원인으로 유발 된 이독성 보호 효과 그리고 난청 이후 인공와우의 보다 나은 결과를 위한 와우 구조들의 보호 두 가지가 있다. 청각 영역에 서의 유전자 치료의 동물 실험은 아주 활발히 진행되고 있지
만, 임상적 사용은 아직 제한적인 상황이다. 따라서 본 리뷰 에서는 각각의 최근 동물 실험결과와 미래 임상적 활용 방안 들에 대해 기술하고자 한다.

내이에서는 다양한 세포들이 청각 전달에 관여한다. 여러 가 지 자극에 의해 쉽게 손상되어 보호가 필요한 구조들로는 유 모세포, 시냅스, 신경 다발, 신경핵 등이 있다. 이 중 유모세포 같은 경우 그 수가 적고 재생이 되지 않기 때문에 가장 중요한 구조이다. ${ }^{23)}$ 이러한 유모세포를 손상시킬 수 있는 원인들로 소 음(청각 과자극), 항암제인 cisplatin, 그리고 aminoglycoside 항생제 등이 대표적이다.

\section{본 론}

\section{소음성 난청에 대한 보호 효과}

문헌에 따르면 미국에서는 약 2천 600만 명의 시민이 소음 으로 인해 청력 손실을 얻었다고 보고될 만큼 ${ }^{4}$ 소음성 난청은 청력 손실을 일으킬 수 있는 가장 흔한 원인 중 하나이다. 작 업 환경, 여가 생활, 사고 상황 등 다양한 경우에서 소음에 노 출이 될 수 있으며, ${ }^{4}$ 이러한 환자들로 인해 발생하는 사회·경 제적으로 적지 않은 손실이 있을 것으로 추측된다. 이러한 현실 때문에 소음성 난청을 최소화하려는 노력이 지속되고 있다. ${ }^{5-9)}$ 최근에 유모세포와 청각 신경 말단을 연결해 주는 시 냅스 연결(ribbon synapse와 post synaptic 수용체) 손상 이후 의 점진적인 신경 손상이 새로운 이론으로 대두되고 있지만, ${ }^{10)}$ 아직까지는 소음성 난청에 대한 영구적 병적 손상의 이유는 유모세포의 손실이라고 생각된다.

이러한 유모세포의 보호 및 시냅스 병변(synaptopathy)의

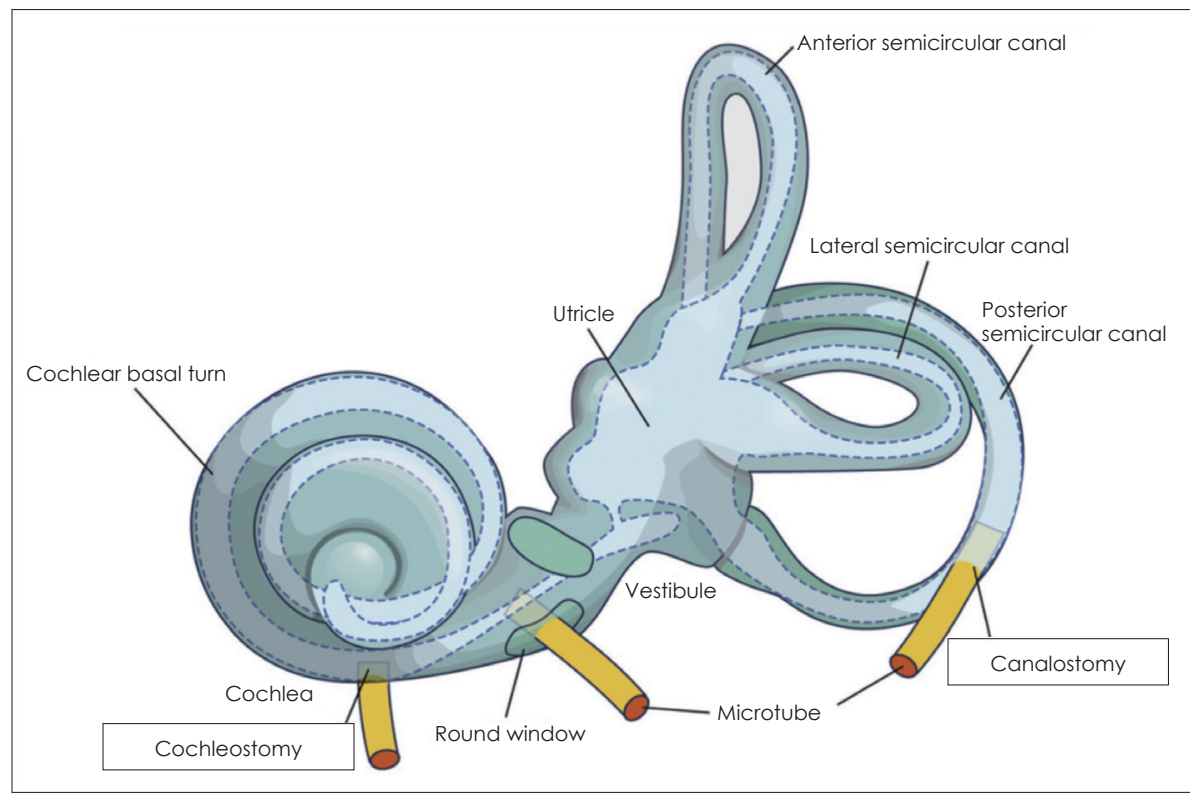

Fig. 1. Schematic image of inner ear showing delivery route for gene therapy. Canalostomy is the technique to deliver the viral vector or other means that carrying gene or possible enhancer or regulator of gene expression to vestibular endolymph. Cochleostomy is the technique that is delivering the factors directly to the cochlea, this could be either perilymph or endolymph delivery. Adapted from Fukui et al. Hear Res 2013;297:99-105. ${ }^{1)}$ 
진행을 예방하기 위해서는 미리 약물을 한 차례 투여하는 것 만으로는 한계가 있다. 소음에 노출되기 전부터 노출이 진행 된 후까지 손상을 예방할 수 있는 인자들이 지속적으로 발 현되어야 한다. 발현수단으로 miniosmotic 펌프 사용, 유전 자 탑재 viral vector 주입, 그리고 매개체를 이용한 약물 분비 등이 있다. ${ }^{11)}$ 이 중 miniosmotic 펌프는 사용 중 펌프 이식 부 위와 cannula 주변 부위의 염증 유발 가능성이 있고, 약물 농 도 유지를 위해 새로운 약물을 재충전해야 하는 불편함이 있 으며, 체온에 의해서 약물의 성격이 변할 가능성이 있다. 또한 viral vector들을 이용한 유전자 치료의 경우도 아직까지 인간 에게 안전하게 사용할 단계의 수준은 아니며 여러 부작용의 가능성들이 있다. ${ }^{1}$ 그럼에도 불구하고 이러한 방법들을 이용 하여 얻은 동물 연구결과들은 추후 적절한 물질을 선택하는 것에 도움을 줄 것이라고 생각된다. Neurotrophin들은 내이 의 분화와 신경 접속을 비롯한 신경계의 발달과 유지에 큰 역 할을 한다. 청각계에서는 brain-derived neurotrophic factor (BDNF)와 neurotrophin-3(NT3)가 청신경계 발달을 위한 중요한 두 가지 neurotrophin들이다. ${ }^{12)}$ 이러한 neurotrophin 들과 항산화제, 그리고 anti-apoptotic 물질들을 포함한 다른 분자 구조들이 소음성 난청 보호 효과를 보이고 있지만,13-17) 이들을 임상적으로 사용하기에는 큰 걸림돌이 있다. 이는 약 물 투여 방법 자체가 침습적이어서 와우에 손상을 일으킬 수 있다는 점이다. 물론 경고막으로 투여할 수도 있지만 아직 이 유전자 치료 방법을 이용하는 것은 그 효과가 직접 투여하는
것에 비해 떨어지는 것으로 알려져 있다. ${ }^{18)}$ 다른 약물 이독성 보호도 그 상황은 비슷하지만, 소음성 난청과는 달리 약물 이 독성의 경우는 사용이 불가피한 경우가 많고, 그 청력의 손실 도 약물 농도에 비례하여 감소하지만, 소음성 난청의 경우 다 양한 변수에 의해 그 난청의 예측이 쉽지 않아서 난청을 일으 킬 수 있는 침습적인 투여를 쉽게 사용할 수는 없다. 또한 최 근 연구에 의하면 정상인 동물에 투여한 neurotrophin을 내 재한 viral vector의 투여가 유모세포의 손상을 유발하지는 않은 채로 청력을 떨어뜨리며, 조직학적으로는 오히려 시냅스 병변을 더 유발하게 되고 신경 말단에 이상 소견을 일으키는 것으로 밝혀졌다(Fig. 2). ${ }^{19)}$ 이 결과는 비단 침습적인 투여 방법 뿐만 아니라 비특이적이고 과잉의 유전자 발현은 적어도 일 시적으로 정상 와우에 부정적인 영향을 끼칠 수 있음을 시사하 고, 그 치료에 적합한 viral vector 선택과 적절한 viral vector 의 치료 용량이 선행되어야 함을 보여준다.

\section{항암제 중 Cisplatin 이독성에 대한 보호 효과}

Cisplatin은 두경부의 편평세포 암종 치료에 흔히 사용되는 화학 치료제이다. ${ }^{20)}$ 하지만 이 약물의 주된 부작용 역시 고주 파수 영역에서 시작되어 저주파수 영역으로 파급되는 감각 신 경성 난청이며, 이 난청은 약물의 용량에 비례한다. ${ }^{21)}$ 이 약물 을 투여받은 환자들이 감각 신경성 난청을 호소하는 경우는 보고에 따라 다르지만 높게는 $62 \%{ }^{22)}$ 에 이르며, 높은 유병률 에 반해서 이러한 이독성을 보호할 수 있는 방법이 아직까지
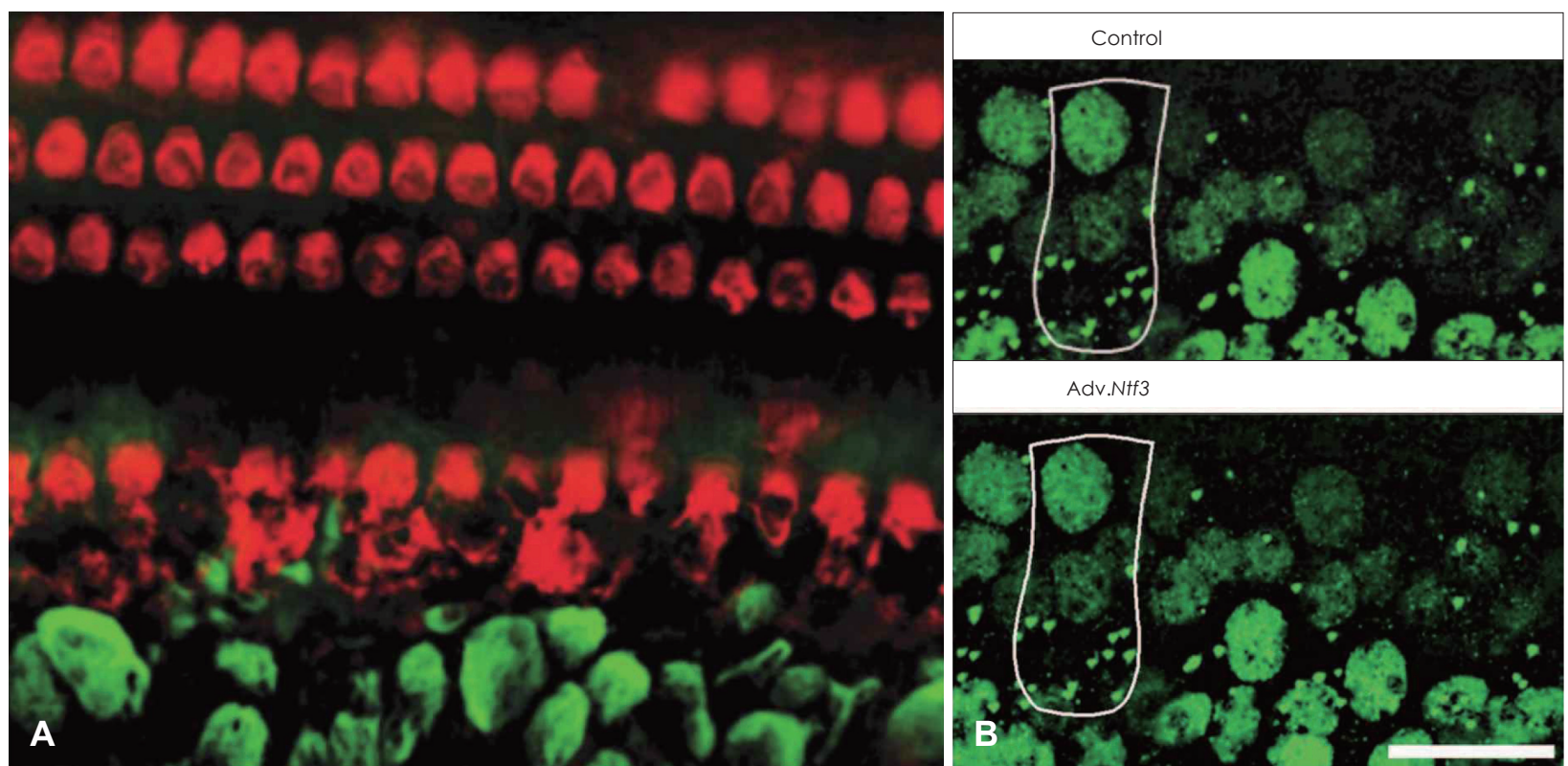

Adv.Ntf3

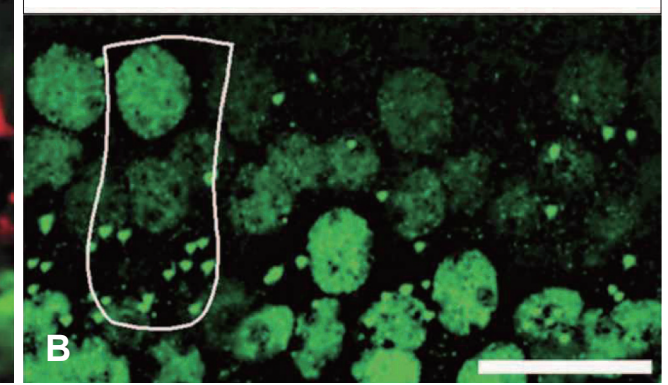

Fig. 2. Representative image showing changes of nervous structures observed in peripheral cochlear nerve after forced overexpression of Ntf3 by gene therapy. Compared to normal density of hair cells (myosin Vlla, red), including inner and outer hair cell, peripheral nerve fibers (neurofilament, green) show deformed morphologies, swollen nerve ending and medialization (A). Synaptic density (Ctbp2, green) of the viral vector treated group were decreased compared to control group (B) (scale bars indicate $20 \mu \mathrm{m}$ ). Adapted from Lee et al. Mol Ther Methods Clin Dev 2016;3:16052. ${ }^{19)}$ Adv.: adeno virus. 
는 없는 실정이다. ${ }^{21}$

위에서 기술한 바와 같이 이러한 cisplatin에 의한 이독성을 보호하기 위해서는 한두 번의 약물 투여가 아닌 지속적인 보 호 물질의 발현이 필요할 수 있으며, 이를 위한 가장 적절한 방 법이 유전자 치료일 것이다. 따라서 어떤 유전자를 전달시켜 그 효과를 최대화할 수 있는지 선택하는 것은 매우 중요하다. 이에 첫 번째로 시도된 물질은 apoptosis의 X-linked 억제 약 물들로 caspase나 다른 cell death pathway를 억제하게 된다. ${ }^{23)}$ 아데노 어소시에트 바이러스(adeno-associated virus, AAV serotype 2)를 viral vector로 이용한 cisplatin 이동성 보호 연구 가 rat을 이용하여 진행되었고, 그 결과 유모세포의 보호 효과 가 있는 것이 밝혀졌다. ${ }^{24)}$ 이 결과는 침습적인 방법으로 전달 한 유전자 치료법과 더불어 비침습적인 경고막 방법 모두에 서 긍정적인 효과를 얻었다는 데 더 큰 의미가 있다. ${ }^{25)}$ 이외에 도 neurotrophins를 viral vector로 전달한 유전자 치료, ${ }^{26}$ 그리 고 siRNA를 이용하여 transient receptor potential vanilloid1 과 signal transducer and activator of transcription ${ }^{27,28)}$ 을 억 제한 연구에서도 긍정적인 결과를 도출하였다.

\section{Aminoglycoside 항생제로 인한 이독성에 대한 보호 효과}

Aminoglycosides 항생제는 1940년대에 개발되었고, 현재 까지 사용되고 있는 오래된 항생제 중 하나이다. ${ }^{29}$ 이 중 하나 가 gentamicin이며 특정한 염증이 있는 경우 ${ }^{30}$ 널리 사용되고 있으며, 최근에는 cystic fibrosis, ${ }^{31)}$ Rett syndrome ${ }^{32-34)}$ 등이 있는 경우 그 증상 조절에 효과가 있다고 보고되고 있다. 물론 aminoglycosides 사용은 신장독성, 이독성 등의 부작용이 있
으며, 특히 이독성으로 인해서 귀의 유모세포와 그와 관련된 신경이 손상을 받게 되면서 ${ }^{35-37)}$ 이독성을 보호 예방하기 위해 다양한 연구들이 진행되었다.

실험적으로 이독성으로부터 보호하기 위해 처음 사용된 물 질은 성장인자(growth factor)이다. 가장 처음 시도되었던 성장 인자는 glial cell line-derived neurotrophic factor(GDNF) 로 결과는 긍정적이었다. 아데노 바이러스(adeno virus)를 viral vector로 사용한 GDNF 유전자 치료는 aminoglycoside 이독 성을 보호하는 효과가 있었으며, ${ }^{38)}$ transforming growth factor $-\beta 1$ 을 같이 사용하였을 때 더 좋은 효과를 얻었다. ${ }^{39)}$ 다른 viral vector인 아데노 어소시에이트 바이러스를 이용하여 같 은 결과를 얻을 수 있었다. ${ }^{40}$ Aminoglycoside에 의한 이독성 으로부터 보호 효과를 보인 또 다른 성장인자는 neurotrophin들이다. 이 경우에는 neurotrophin 자체의 농도를 높이지 않 고 간접적으로 receptor의 발현을 증가시켜서 그 보호 효과를 확인할 수 있었다. ${ }^{41)}$

성장인자 외에 다른 분자 구조들도 실험을 통해 aminoglycoside에 의한 이독성으로부터 보호 효과가 있다고 보고 되었다. 그중 하나가 apoptosis를 억제하는 bcl-2의 과발현을 이용하여 세포의 죽음을 멈추게 하는 것으로, 아데노 바이러 스를 viral vector로 $b c l-2$ 유전자를 이용한 유전자 치료는 와 우와 전정 기관 모두에서 경고막 aminoglycoside 이독성에 보호 효과를 보였다. ${ }^{42)}$

또한 최근 heat-shock protein(Hsp) 과발현을 이용하여 이 독성으로부터 유모세포를 보호한 연구들이 발표되었다. ${ }^{4-45)}$ 이러한 연구 중에 아데노 바이러스를 이용한 $H s p 70$ 유전자 치
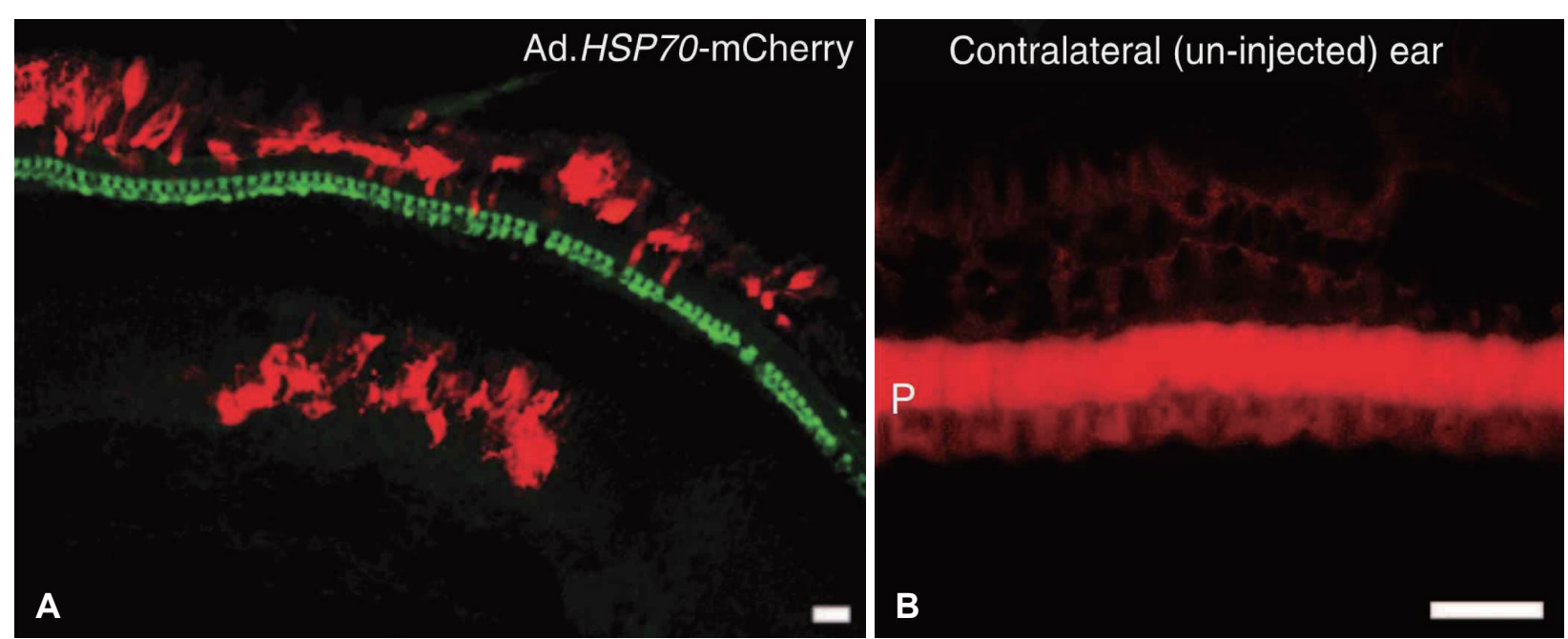

Fig. 3. Representative image showing the protected inner hair cell (green) (A) in the ear treated by Adv.Hsp70 and damaged hair cells (B) in the control ear. After the aminoglycoside ototoxicity inner hair cells were preserved in $\mathrm{Hsp} 70$ overexpressed ear by Adv. gene therapy. Hair cells were stained by myosin Vlla which are expressed in green, Tdtomato which is expressed by cells that are transfected by Adv. are expressed in red (A). Ears without viral gene therapy showed massive damage of hair cell showing phalangeal scar formation (P: pillar cells), image is stained with phalloidin (B) (scale bars indicate $20 \mu \mathrm{m}$ ). Adapted from Takada et al. Mol Ther Methods Clin Dev 2015;2:15019. ${ }^{45}$ Adv.: adeno virus, Hsp: heat-shock protein. 
료가 시도되었다. 결과를 간략히 설명하자면, $H s p 70$ 유전자 치료가 시행된 귀는 aminoglycoside가 투여되어 이독성이 생 긴 반대측 귀에 비해 청력 손실의 정도도 적었고, 외유모세 포의 보호 효과는 높지 않았지만 내유모세포의 충분한 보호 효과가 확인되었다(Fig. 3). ${ }^{45)}$ 이 결과는 청각계에서 Hsp를 이 용한 첫 유전자 치료의 결과이다.

항산화제들은 쉽게 구할 수 있고 경구로 섭취할 수 있기 때 문에 항상 쉽게 사용되며, 실험도 용이하여 이독성의 보호 효 과를 임상적으로 확인하려는 시도들이 진행되고 있다. ${ }^{46)}$ 이러 한 항산화제들을 이용한 유전자 치료도 시도되었고 긍정적 인 결과를 보였다. ${ }^{47-49)}$ 이처럼 aminoglycoside에 의한 이독 성을 보호하기 위해 많은 유전자들이 시도되었고, 그중 주목 할 만한 결과는 최근 $\mathrm{Hsp}$ 를 이용한 실험 결과가 아닌가 한다. 아직 그 기능과 역할이 추가적으로 있을 것으로 생각되는 단 백질이므로, 향후 다른 연구들이 진행되고, 긍정적인 결과들 이 도출될 것으로 생각된다.

\section{신경 보호를 통한 인공와우 효과 증대}

최근 조직 공학의 발달로 인해 여러 전문가들이 인공와우 후의 환자들의 청력을 보다 향상시키려고 노력하고 있다. 대 표적으로는 이미 고도 난청이 있지만, 와우 내의 여러 구조물 들의 퇴화나 이차적 손상을 막음으로써 이를 이룰 수 있다는 주장이 있다. ${ }^{50)}$ 연구를 통해서 신경세포, 신경 구조 등의 유지
가 인공와우의 치료 결과와 상관관계가 있음이 밝혀졌고, ${ }^{51,52)}$ 유모세포가 남아 있어서 잔청이 있는 경우에도 그 결과가 양호 함이 알려졌다. ${ }^{53)}$ 사실 신경핵의 밀도와 인공와우 결과와의 상 관성은 명백하지 않지만, 좋은 결과를 얻으려면 어느 정도 이 상의 신경핵의 밀도가 필요하다는 결과가 의견 일치를 이루 고 있다. ${ }^{54)}$ 그리하여 최근 많은 연구들이 와우 신경핵의 생존 을 높일 수 있는 방법을 찾는 것에 집중하고 있다.

일단 유모세포가 전혀 없는 전농 와우에서 와우 신경핵의 생 존율을 높이는 연구에는 아주 다양한 물질들이 사용되어 왔다. 역시 가장 흔히 대두되고 사용되는 물질은 성장인자인 neurotrophins이다. ${ }^{55)}$ 초기에는 neurotrophin을 miniosmotic 펌프 로 투여하여 유모세포와 신경들을 회복시켰다. ${ }^{56)}$ 하지만 viral vector를 이용한 유전자 치료가 가능해지고 나서 대부분의 연구들은 효과적으로 신경핵을 보호할 수 있는 유전자 치료 를 사용해서 진행을 하고 있으며, 대표적인 neurotrophin인 $\mathrm{NT} 3$ 와 $\mathrm{BDNF}$ 가 긍정적인 효과를 보였다. ${ }^{57-60)}$ 신경핵을 보 호하는 것뿐만 아니라, 신경 말단 자체를 전극 자체로 가깝 게 이동시키는 것이 저항을 줄이고 전류의 이동을 확산시켜 더 나은 효과를 낳을 수 있다. Neurotrophin들을 이용한 유 전자 치료 이후에 신경 말단들이 전극이 위치할 곳으로 자라 나는 것이 확인되었고(Fig. 4), ${ }^{58-61)}$ 유전자 치료 후 각종 청각 기능 검사들을 통해 긍정적인 결과를 확인하였지만 새로 자 라난 신경 다발의 유무와 검사 결과 상승의 직접적인 상관
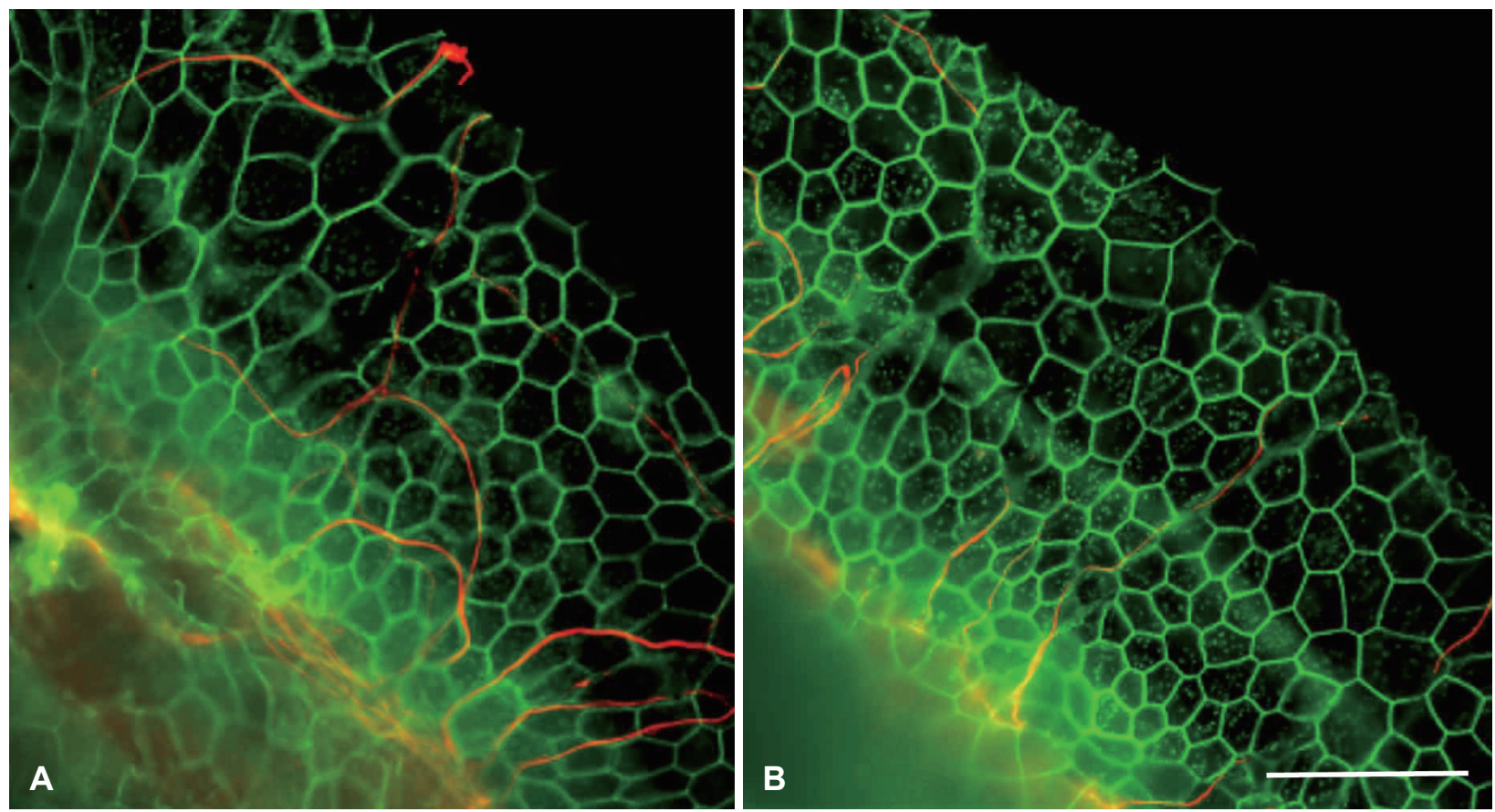

Fig. 4. Representative image showing peripheral nerve (red) migration after neurotrophin gene therapy. Cochleae were pre-damaged using ototoxic drug, showing flat epithelium expressed by honeycomb shape of actin fibers (phalloidin, green). Both cochleae treated with Adv.Ntf3 (A) and Adv.BDNF (B) shows migration of thin peripheral nerve fibers toward the lateral part of organ of Corti (scale bars indicate $50 \mu \mathrm{m})$. Adapted from Budenz et al. Sci Rep 2015;5:8619. ${ }^{60)}$ Adv.: adeno virus, BDNF: brain-derived neurotrophic factor. 
관계를 확인하는 것은 어려웠다. 이는 새로 생긴 신경 다발이 unmyelinated 신경이어서 전도 속도가 느리기 때문으로 추측 해 볼 수 있지만, 추가적인 연구가 필요할 것으로 생각된다. 앞 서 기술했 듯이 neurotrophin들은 유모세포를 여러 가지 자극 으로부터 보호할 수 있다. 이를 통해 잔청이 유지되게 되면 이 또한 인공와우의 효과를 상승시키는 효과가 있을 것으로 생각 된다.

물론 위의 실험적인 방법들을 임상적으로 실제 난청 환자 의 인공와우 수술에 사용하려면 viral vector의 부작용과 치 료의 지속시간, 그리고 치료로 실제로 얻을 수 있는 기능적 효 과에 대한 면밀 조사 이후 진행시켜야 할 것이다. 하지만 동물 실험을 통한 결과가 매우 긍정적인 것을 감안하면, neurotrophin과 myelination을 유도할 수 있는 물질을 조합해서 사 용하게 된다면 충분히 인공와우의 결과를 향상시킬 수 있는 방법이 될 것으로 보인다. 그리고 인공와우 수술 자체가 정원 창을 열고 전극을 삽입해야 하는 침습적인 과정이므로, 이 과 정을 통해서 추가적인 침습적인 작업 없이 치료를 할 수 있 다. 그러므로 저자는 위에서 기술했던 한계점들이 극복된다 면 인공와우 수술이 임상적으로 유전자 치료가 도입될 가능 성이 가장 큰 분야라고 생각된다.

\section{결 론}

보호 치료이기 때문에 만약 치료 과정에서 득보다 실이 많다 면 그 치료 방법은 사용할 수 없다. 그렇기 때문에 전달 과정 이 매우 중요하며, 그 전달 과정이 침습적이지 않고 와우 유모 세포나 신경의 손상이 생기면 안 된다. 한 가지 다른 방법으 로 이독성이건 소음성 난청이건 노출 후 즉시 처치하여 치료 효과를 기대해 볼 수 있겠다. 하지만 이 두 가지 방법 모두 현 실적인 의료 상황에서 쉽게 사용될 가능성이 높지 않아 보인다. 하지만 시간이 지날수록 보다 좋은 약물 전달 물질들이 개발 되고 있고, viral vector들도 그 세포 선택 능력이나 transduction 비율 측면에서 발전하고 있으므로, 추후 이들의 발전 경 과를 지켜보며 추가 연구들을 진행해야 하겠다. 인공와우의 보조 요법으로서 유전자 치료의 사용은 멀지 않은 시기에 가능해 보인다. 물론 유전자 치료에 사용되는 viral vector의 안정성 확보가 필요하지만 다른 영역에서 이미 유전자 치료의 사용이 임상 시험으로 시도되고 있는 것(2)을 감안하면 이 또 한 곧 극복될 것으로 생각한다.

"Bench to clinic"이라는 문장이 중요시되는 시기이다. 많은 연구들이 실험실에서는 긍정적인 효과를 보고 있지만 이를 임상적으로 적용하는 것에는 난항을 겪고 있다. 유전자 치료 역시 이들 중에 하나였다. 하지만 많은 기술의 발전과 연구들
로 몇몇 연구기관 및 병원에서는 유전자 치료 임상 시험들이 시도되고 긍정적인 결과를 얻고 있으며, 감각 신경성 난청과 같은 난치성 질환의 경우 현재 치료 방법이 없기 때문에 새로 운 치료 방법인 유전자 치료 방법 확립이 절실한 상황이다. 여 러 이전 연구들을 돌아보면 유전자 치료의 적용이 요원해 보 이지만은 않는다. 보다 선도적인 연구자들의 적극적인 시도들 과 기초 기반 연구들이 풍성하게 진행된다면 유전자 치료에 의한 난청 극복이 어려운 것만은 아닐 것으로 생각한다.

\section{REFERENCES}

1) Fukui H, Raphael Y. Gene therapy for the inner ear. Hear Res 2013; 297:99-105.

2) Roberson DW, Rubel EW. Cell division in the gerbil cochlea after acoustic trauma. Am J Otol 1994;15(1):28-34.

3) Izumikawa M, Batts SA, Miyazawa T, Swiderski DL, Raphael Y. Response of the flat cochlear epithelium to forced expression of Atoh1. Hear Res 2008;240(1-2):52-6.

4) Clifford RE, Rogers RA. Impulse noise: theoretical solutions to the quandary of cochlear protection. Ann Otol Rhinol Laryngol 2009; 118(6):417-27.

5) Folmer RL, Griest SE, Martin WH. Hearing conservation education programs for children: a review. J Sch Health 2002;72(2):51-7.

6) Verbeek JH, Kateman E, Morata TC, Dreschler W, Sorgdrager B. Interventions to prevent occupational noise induced hearing loss. Cochrane Database Syst Rev 2009;(3):CD006396.

7) Kopke RD, Jackson RL, Coleman JK, Liu J, Bielefeld EC, Balough BJ. NAC for noise: from the bench top to the clinic. Hear Res 2007;226 (1-2):114-25.

8) Le Prell CG, Hughes LF, Miller JM. Free radical scavengers vitamins $\mathrm{A}, \mathrm{C}$, and $\mathrm{E}$ plus magnesium reduce noise trauma. Free Radic Biol Med 2007;42(9):1454-63.

9) Seidman MD, Tang W, Bai VU, Ahmad N, Jiang H, Media J, et al. Resveratrol decreases noise-induced cyclooxygenase-2 expression in the rat cochlea. Otolaryngol Head Neck Surg 2013;148(5):827-33.

10) Kujawa SG, Liberman MC. Synaptopathy in the noise-exposed and aging cochlea: primary neural degeneration in acquired sensorineural hearing loss. Hear Res 2015;330(Pt B):191-9.

11) Noushi F, Richardson RT, Hardman J, Clark G, O'Leary S. Delivery of neurotrophin-3 to the cochlea using alginate beads. Otol Neurotol 2005;26(3):528-33.

12) Pirvola U, Ylikoski J, Palgi J, Lehtonen E, Arumäe U, Saarma M. Brain-derived neurotrophic factor and neurotrophin 3 mRNAs in the peripheral target fields of developing inner ear ganglia. Proc Natl Acad Sci U S A 1992;89(20):9915-9.

13) Shoji F, Miller AL, Mitchell A, Yamasoba T, Altschuler RA, Miller JM. Differential protective effects of neurotrophins in the attenuation of noise-induced hair cell loss. Hear Res 2000;146(1-2):134-42.

14) Bielefeld EC. Reduction in impulse noise-induced permanent threshold shift with intracochlear application of an NADPH oxidase inhibitor. J Am Acad Audiol 2013;24(6):461-73.

15) Du X, Choi CH, Chen K, Cheng W, Floyd RA, Kopke RD. Reduced formation of oxidative stress biomarkers and migration of mononuclear phagocytes in the cochleae of chinchilla after antioxidant treatment in acute acoustic trauma. Int J Otolaryngol 2011;2011:612690.

16) Yamashita D, Jiang HY, Le Prell CG, Schacht J, Miller JM. Postexposure treatment attenuates noise-induced hearing loss. Neuroscience 2005;134(2):633-42.

17) Coleman JK, Littlesunday C, Jackson R, Meyer T. AM-111 protects against permanent hearing loss from impulse noise trauma. Hear Res 2007;226(1-2):70-8. 
18) Kurioka T, Mizutari K, Niwa K, Fukumori T, Inoue M, Hasegawa M, et al. Hyaluronic acid pretreatment for Sendai virus-mediated cochlear gene transfer. Gene Ther 2016;23(2):187-95.

19) Lee MY, Kurioka T, Nelson MM, Prieskorn DM, Swiderski DL, Takada Y, et al. Viral-mediated Ntf3 overexpression disrupts innervation and hearing in nondeafened guinea pig cochleae. Mol Ther Methods Clin Dev 2016;3:16052.

20) Gonçalves MS, Silveira AF, Teixeira AR, Hyppolito MA. Mechanisms of cisplatin ototoxicity: theoretical review. J Laryngol Otol 2013;127 (6):536-41

21) Chirtes F, Albu S. Prevention and restoration of hearing loss associated with the use of cisplatin. Biomed Res Int 2014;2014:925485.

22) Marshak T, Steiner M, Kaminer M, Levy L, Shupak A. Prevention of cisplatin-induced hearing loss by intratympanic dexamethasone: a randomized controlled study. Otolaryngol Head Neck Surg 2014; 150(6):983-90

23) Deveraux QL, Takahashi R, Salvesen GS, Reed JC. X-linked IAP is a direct inhibitor of cell-death proteases. Nature 1997;388(6639): $300-4$.

24) Cooper LB, Chan DK, Roediger FC, Shaffer BR, Fraser JF, Musatov $\mathrm{S}$, et al. AAV-mediated delivery of the caspase inhibitor XIAP protects against cisplatin ototoxicity. Otol Neurotol 2006;27(4):484-90.

25) Jie H, Tao S, Liu L, Xia L, Charko A, Yu Z, et al. Cochlear protection against cisplatin by viral transfection of X-linked inhibitor of apoptosis protein across round window membrane. Gene Ther 2015;22(7): 546-52.

26) Bowers WJ, Chen X, Guo H, Frisina DR, Federoff HJ, Frisina RD. Neurotrophin-3 transduction attenuates cisplatin spiral ganglion neuron ototoxicity in the cochlea. Mol Ther 2002;6(1):12-8.

27) Mukherjea D, Jajoo S, Whitworth C, Bunch JR, Turner JG, Rybak $\mathrm{LP}$, et al. Short interfering RNA against transient receptor potential vanilloid 1 attenuates cisplatin-induced hearing loss in the rat. J Neurosci 2008;28(49):13056-65.

28) Mukherjea D, Jajoo S, Kaur T, Sheehan KE, Ramkumar V, Rybak LP. Transtympanic administration of short interfering (si)RNA for the NOX3 isoform of NADPH oxidase protects against cisplatininduced hearing loss in the rat. Antioxid Redox Signal 2010;13(5): 589-98

29) Chen LF, Kaye D. Current use for old antibacterial agents: polymyxins, rifamycins, and aminoglycosides. Infect Dis Clin North Am 2009; 23(4):1053-75, x.

30) Chen C, Chen Y, Wu P, Chen B. Update on new medicinal applications of gentamicin: evidence-based review. J Formos Med Assoc 2014; 113(2):72-82

31) Xue X, Mutyam V, Tang L, Biswas S, Du M, Jackson LA, et al. Synthetic aminoglycosides efficiently suppress cystic fibrosis transmembrane conductance regulator nonsense mutations and are enhanced by ivacaftor. Am J Respir Cell Mol Biol 2014;50(4):805-16.

32) Popescu AC, Sidorova E, Zhang G, Eubanks JH. Aminoglycosidemediated partial suppression of MECP2 nonsense mutations responsible for Rett syndrome in vitro. J Neurosci Res 2010;88(11):2316-24.

33) Brendel C, Klahold E, Gärtner J, Huppke P. Suppression of nonsense mutations in Rett syndrome by aminoglycoside antibiotics. Pediatr Res 2009;65(5):520-3.

34) Brendel C, Belakhov V, Werner H, Wegener E, Gärtner J, Nudelman I, et al. Readthrough of nonsense mutations in Rett syndrome: evaluation of novel aminoglycosides and generation of a new mouse model. J Mol Med (Berl) 2011;89(4):389-98.

35) Hawkins JE Jr, Stebbins WC, Johnsson LG, Moody DB, Muraski A. The patas monkey as a model for dihydrostreptomycin ototoxicity. Acta Otolaryngol 1977;83(1-2):123-29.

36) Schacht J. Biochemistry and pharmacology of aminoglycosideinduced hearing loss. Acta Physiol Pharmacol Ther Latinoam 1999; 49(4):251-6.
37) Johnsson LG, Hawkins JE Jr, Kingsley TC, Black FO, Matz GJ. Aminoglycoside-induced cochlear pathology in man. Acta Otolaryngol Suppl 1981;383:1-19.

38) Yagi M, Magal E, Sheng Z, Ang KA, Raphael Y. Hair cell protection from aminoglycoside ototoxicity by adenovirus-mediated overexpression of glial cell line-derived neurotrophic factor. Hum Gene Ther 1999; 10(5):813-23.

39) Ben-Yosef T, Belyantseva IA, Saunders TL, Hughes ED, Kawamoto $\mathrm{K}$, Van Itallie CM, et al. Claudin 14 knockout mice, a model for autosomal recessive deafness DFNB29, are deaf due to cochlear hair cell degeneration. Hum Mol Genet 2003;12(16):2049-61.

40) Liu Y, Okada T, Shimazaki K, Sheykholeslami K, Nomoto T, Muramatsu S, et al. Protection against aminoglycoside-induced ototoxicity by regulated $\mathrm{AAV}$ vector-mediated GDNF gene transfer into the cochlea. Mol Ther 2008;16(3):474-80.

41) Yu Q, Chang Q, Liu X, Wang Y, Li H, Gong S, et al. Protection of spiral ganglion neurons from degeneration using small-molecule TrkB receptor agonists. J Neurosci.2013;33(32):13042-52.

42) Pfannenstiel SC, Praetorius M, Plinkert PK, Brough DE, Staecker $\mathrm{H}$. Bcl-2 gene therapy prevents aminoglycoside-induced degeneration of auditory and vestibular hair cells. Audiol Neurootol 2009;14(4): 254-66.

43) Taleb M, Brandon CS, Lee FS, Harris KC, Dillmann WH, Cunningham LL. Hsp70 inhibits aminoglycoside-induced hearing loss and cochlear hair cell death. Cell Stress Chaperones 2009;14(4):427-37.

44) Baker TG, Roy S, Brandon CS, Kramarenko IK, Francis SP, Taleb $\mathrm{M}$, et al. Heat shock protein-mediated protection against cisplatininduced hair cell death. J Assoc Res Otolaryngol 2015;16(1):67-80.

45) Takada Y, Takada T, Lee MY, Swiderski DL, Kabara LL, Dolan $\mathrm{DF}$, et al. Ototoxicity-induced loss of hearing and inner hair cells is attenuated by HSP70 gene transfer. Mol Ther Methods Clin Dev 2015;2:15019

46) Chen Y, Huang WG, Zha DJ, Qiu JH, Wang JL, Sha SH, et al. Aspirin attenuates gentamicin ototoxicity: from the laboratory to the clinic. Hear Res 2007;226(1-2):178-82.

47) Ojano-Dirain CP, Antonelli PJ, Le Prell CG. Mitochondria-targeted antioxidant MitoQ reduces gentamicin-induced ototoxicity. Otol Neurotol 2014;35(3):533-9.

48) Kawamoto K, Sha SH, Minoda R, Izumikawa M, Kuriyama H, Schacht J, et al. Antioxidant gene therapy can protect hearing and hair cells from ototoxicity. Mol Ther 2004;9(2):173-81.

49) Song BB, Schacht J. Variable efficacy of radical scavengers and iron chelators to attenuate gentamicin ototoxicity in guinea pig in vivo. Hear Res 1996;94(1-2):87-93.

50) Pfingst BE, Zhou N, Colesa DJ, Watts MM, Strahl SB, Garadat SN, et al. Importance of cochlear health for implant function. Hear Res 2015;322:77-88.

51) Pfingst BE, Hughes AP, Colesa DJ, Watts MM, Strahl SB, Raphael Y. Insertion trauma and recovery of function after cochlear implantation: evidence from objective functional measures. Hear Res 2015;330(Pt A):98-105.

52) Landry TG, Fallon JB, Wise AK, Shepherd RK. Chronic neurotrophin delivery promotes ectopic neurite growth from the spiral ganglion of deafened cochleae without compromising the spatial selectivity of cochlear implants. J Comp Neurol 2013;521(12):2818-32.

53) Miranda PC, Sampaio AL, Lopes RA, Ramos Venosa A, de Oliveira CA. Hearing preservation in cochlear implant surgery. Int J Otolaryngol 2014;2014:468515.

54) Fayad JN, Linthicum FH Jr. Multichannel cochlear implants: relation of histopathology to performance. Laryngoscope 2006;116(8): 1310-20.

55) Budenz CL, Pfingst BE, Raphael Y. The use of neurotrophin therapy in the inner ear to augment cochlear implantation outcomes. Anat Rec (Hoboken) 2012;295(11):1896-908. 
56) Miller JM, Chi DH, O’Keeffe LJ, Kruszka P, Raphael Y, Altschuler RA. Neurotrophins can enhance spiral ganglion cell survival after inner hair cell loss. Int J Dev Neurosci 1997;15(4-5):631-43.

57) Nakaizumi T, Kawamoto K, Minoda R, Raphael Y. Adenovirusmediated expression of brain-derived neurotrophic factor protects spiral ganglion neurons from ototoxic damage. Audiol Neurootol 2004;9(3):135-43.

58) Shibata SB, Cortez SR, Beyer LA, Wiler JA, Di Polo A, Pfingst BE, et al. Transgenic BDNF induces nerve fiber regrowth into the auditory epithelium in deaf cochleae. Exp Neurol 2010;223(2):464-72.

59) Wise AK, Hume CR, Flynn BO, Jeelall YS, Suhr CL, Sgro BE, et al. Effects of localized neurotrophin gene expression on spiral ganglion neuron resprouting in the deafened cochlea. Mol Ther 2010;18(6): 1111-22.

60) Budenz CL, Wong HT, Swiderski DL, Shibata SB, Pfingst BE, Raphael Y. Differential effects of AAV.BDNF and AAV.Ntf3 in the deafened adult guinea pig ear. Sci Rep 2015;5:8619.

61) Wise AK, Tu T, Atkinson PJ, Flynn BO, Sgro BE, Hume C, et al. The effect of deafness duration on neurotrophin gene therapy for spiral ganglion neuron protection. Hear Res 2011;278(1-2):69-76.

62) Stoica L, Sena-Esteves M. Adeno associated viral vector delivered RNAi for gene therapy of SOD1 amyotrophic lateral sclerosis. Front Mol Neurosci 2016;9:56.

\section{정답 및 해설}

답 NUT midline carcinoma

해 설 Nuclear protein in testis(NUT) midline carcinoma는 드물고 높은 사망률을 보이지만 병리조직학적 검사만으로는 진단 이 어려운 질환이다. 이에 위 논문의 저자들은 비부비동 영역에서 발생한 저분화 또는 미분화암종에 대해 NUT 면역조직 화학검사를 시행하여 빠른 진단과 치료가 시행되어야 함을 강조하고 있다. 치료에 대해서는 아직 정립되어 있지 않으며, 좀 더 빠른 시기에 방사선 치료를 시작할수록, 육안적으로 종양 전절제가 가능했을 때 생존 기간이 증가한다고 알려져 있다.

참고문헌: Lee M, Kang YS, Won TB, Kim HJ. Two cases of nuclear protein in testis midline carcinomas of sinonasal tract. Korean J Otorhinolaryngol-Head Neck Surg 2017 Jan 26 [Epup ahead of print]. https://doi.org/ 10.3342/kjorl-hns.2016.17272. 